\title{
Evaluation of the religious education in the catechetical program of the University of Saint Louis
}

\author{
Temporal, Wilson $\$ \\ University of Saint Louis, Tuguegarao City, Philippines (wilson_temporal@dlsu.edu.ph)
}

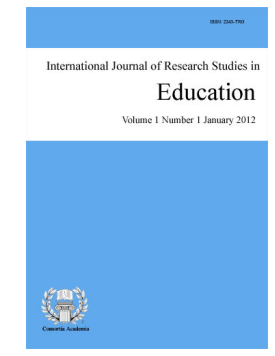

ISSN: $2243-7703$ Online ISSN: 2243-7711

OPEN ACCESS

\section{Abstract}

This study employed mixed methods with thematic analysis of USL's response and program alignment and through a survey method with complete enumeration and ranking to evaluate the existing trends in the Religious Education in the Catechetical Program of USL such as students' perceptions of their catechists' performance and the values imbibed in them. Respondents were student-catechists of USL and the public elementary pupils who received catechesis from them. Results show that pupils claim that they often observe the concepts expected of them to have in catechetical instruction and that they imbibed to a very great extent the values taught them most especially the values of courtesy and compassion. Also, the student-catechists view the Catechetical program to be very efficient with most of them utilizing sacraments, parables, Bible stories, the Ten Commandments, prayers, Christian songs or animation songs, the gifts of the Holy Spirit, Corporal-Spiritual Works of Mercy, and the Theological-Cardinal virtues as their content materials. Relative to the content of the student-catechists' lessons, most catechists integrate the values of love, Faith and trust, respect and or courtesy. Strikingly, the values they least integrated in their lessons is on obedience. Along methodology, most of the student-catechists employed story-telling as their teaching-learning activity. Student-catechists' recommendations for the program's improvement rests upon the formative goals of their being teacher-education students. Religious education in the catechetical program of USL delivered in the public elementary schools adheres to the content and methodology as expected in the program. However, there is a need to reconcile these content and methodology in the light of principles of learning and methods of teaching applied in Religious Education.

Keywords: catechetical program; catechetical instruction; content; values; methodology; religious education 


\section{Evaluation of the religious education in the catechetical program of the University of Saint Louis}

\section{Introduction}

The Catholic Religious Education in the Philippines occurs within formal religious education classroom settings, as well as in activities outside formal classroom such as but not limited to liturgies, recollections or retreats, social justice activities, and evangelizing mission or catechism.

Emphatically, the religious education offered in CICM schools reflects real-life learning in conjunction with the essence of catechism which necessitates that classroom encounters should actually lead the pupils to an understanding and experience of the Catholic faith through shepherding and through becoming God's storytellers (Cura, 2016). Such religious education concept is necessary for the catechetical program of the University of Saint Louis Tuguegarao (USL), a CICM school. To situate the development of the role of the University's Catechetical Program, it is necessary to examine its beginnings and present state.

USL, a Catholic institution run by the Congregation of the Immaculate Heart of Mary (CICM), has a catechetical ministry to public elementary schools. The University's catechetical program (which actively involves the 3rd year SEASH students under the Teacher Education Program and the appointed USL Catechetical Coordinator) started in Cataggaman, Tuguegarao City in the early 90's. Catechetical Coordinators and parish priests had to tandem for catechesis in the classrooms of Grades 1- 6 pupils, particularly in giving of confessions, preparations for the First Holy Communion, Baptism for those who would like to embrace the Catholic faith, and administration of the Sacrament of Confirmation. Indeed, there were a good number of student-catechists to cater to Cataggaman Elementary School, Pardo Elementary School, and Cataggaman Nuevo Elementary School. Inevitably, the catechetical program of USL in Cataggaman was transferred to Sta. Rosa De Lima Parish on June 2013 until December 2015 (which catered to Annafunan Elementary School and Atulayan Elementary School). For the SY 2016-2017, the catechetical program of USL is already in Tuguegarao West Central School; and recently placed back again to St. Dominic De Guzman Parish (catering to Cataggaman Nuevo Elementary School, Cataggaman Elementary School - main, and Cataggaman Pardo Elementary School).

Preparatory measures for the program implementation were always considered. Specifically, seminars for the student-catechists were conducted before their actual catechesis and even during the school year. Catechism course outlines were done and lesson plans were submitted. Responsible students were elected as officers and indeed helped much the Catechetical Coordinator. Also, mid-year recollection is sometimes given to the student-catechists for their spiritual formation. USL administration, particularly the office of the Vice-President for Mission and Identity (also the University Chaplain), and the office of the SEAS Dean, is very supportive to the catechetical program. In fact, the University is spending much for the catechetical endeavor, with an annual budget of more or less thirty thousand pesos.

With the attention and emphasis given to the program and with no study that had yet assessed its implementation, this study was conceived. It is with hope that through this study, USL's religious education in its catechetical program become more stable, more responsive and more distinct of its identity.

\subsection{Research objective/questions}

This study aimed to evaluate the content and delivery of the religious education in the current Catechetical Program of the University of Saint Louis. Specifically, it sought to answer the following questions:

$>\quad$ What content materials do student-catechists utilize in their religious instruction? 
Evaluation of the religious education in the catechetical program of the University of Saint Louis

$>$ What teaching-learning activities are employed by student-catechists in their catechism?

$>$ What values are integrated by student-catechists in their catechetical lessons?

$>\quad$ What is the extent of pupils' learning from the religious instruction in the Catechetical Program of USL?

$>\quad$ To what extent do catechists and elementary pupils imbibe the values they learned from the Religious Education in the catechetical program of USL?

$>\quad$ What are the pupils' perception and recommendations of their student-catechists' religious instruction?

$>\quad$ To what extent is the efficiency of the Religious Education in the Catechetical Program of USL with regard its content and delivery?

$>\quad$ What are the student-catechists' perceptions and recommendations of the content and methodology in the religious education of the catechetical program of USL?

\section{Literature review}

\subsection{Theories of religious education drawn from primary sources}

In order to analyze the role of religious education in the catechetical program, it is imperative to understand the nature of religious education in Catholic schools. Many terms have been used to describe its essential nature and characteristics including catechesis, religious education, religious instruction, evangelization, and religious studies. In this paper, the term 'religious education' shall be used following Fleming's (2002) scope to be inclusive of all other terms that are used for, and associated with, religious education in authoritative Church documents because it is the most common term in the school context.

The Church document Catechesi Tradendae reinforces the links between catechesis and evangelization captured in the paragraph 18 of the document which states that these two terms "have close links whereby they integrate and complement each other" and between which "there is no separation or opposition". Evangelization is the first step of the process that leads to catechesis:

To put it more precisely: within the whole process of evangelization, the aim of catechesis is to be the teaching and maturation stage, that is to say, the period in which the Christian, having accepted by faith the person of Jesus Christ as the one Lord, and having given him complete adherence by sincere conversion of heart (para. 20).

On a different note, The General Directory for Catechesis presents the relationship between religious instruction in schools and catechesis which is one of distinction and complementarity, articulating the importance of the cognitive demands of religious education in schools and the need to present it with the same rigor at other subjects. Emphatically, the Sacred Congregation for Catholic Education produced documents one of which addresses the nature of The Catholic School (CS) as part of the mission of the Church; hence, can be places of evangelization. This document further describes schools as places where the young are exposed to the world (para. 27), where they have the opportunity to develop ethical approaches to life (para. 30), and where values can be explored (para. 32). The document also explores the teaching of religious education, and presents a theory of religious education in schools which is not confined to religious education classes:

Without entering into the whole problem of teaching religion in schools it must be emphasized that, while such teaching is not merely confined to "religious classes" within the school curriculum, it must, nevertheless, also be imparted explicitly and in a systematic manner to prevent distortion in the child's mind between religious and other forms of education (para. 50). 
Schools, on this note, assist catechesis when "young people are helped to grow towards maturity of faith" (para. 51). It must be stressed at this point that 'catechesis' is the preferred term for religious education widely used in the above-cited documents.

\subsection{Fundamental principles of catechesis}

His Holiness, the late pope, saint John Paul II, stated in his encyclical Catechesis in Our Time (Catechesi Tradendae) that "the definitive aim of catechesis is to put people not only in touch but in communion, in intimacy, with Jesus Christ: only he can lead us to the love of the Father in the Spirit and make us share in the life of the Holy Trinity." Catechesis then must be distinguished from all other ways of presenting the word of God as stressed also by Pope Paul VI.

As posited by Burke (2000), catechesis helps Christians to be changed in their quest for communion with God through the formation that they receive. Indeed, through catechesis, Christian doctrines will be taught with zeal in an "organic and systematic way" that everyone may be formed completely to a holistic Christian life. Catechesis is likely to address the "tension between method and content" as people in the society expect that the faith experience is related to their culture. The fullness of Christian faith embedded in culture should not be undermined.

Catechesis is understandably an essential means of evangelization in reference to the Holy Scriptures and Christian Traditions. It helps nurture the Christian way of life not just in knowledge of Church doctrines but as well of faith and morals. The faith that is exhibited finds meaning with the Liturgy celebrated in the name of Jesus in prayers and in actions aided with liturgical symbols.

\subsection{Understanding catechesis as a work of evangelization}

Many Christians do not understand that catechesis is a concern of everyone baptized in the Faith. The success and fruitfulness of catechesis depend on this awareness. Everyone must respond to the call to be witnesses to the Gospel. It is not only the lay catechists nor the student-catechists (like that of USL) who have the share of catechizing in the public schools and in the parishes. The National Catechetical Directory of the Philippines (NCDP) makes it clear that evangelization is the most common term for catechesis. It is frequently used in two different senses: either as the initial conversion-bringing proclamation of the Gospel, or the total process of bringing the Good News to the whole of humanity. Therefore, in the whole process of evangelization, catechesis is the subsequent activity that relates to it in a very remarkable manner.

Understanding catechesis as a work of evangelization is to move from the Christological model of mission to the new model, whereas, every Christian is called to be missionary because of his baptism. Mission proceeds from Baptism and not from a special mandate received from ecclesial authority (Mercado, 1992).

\subsection{Inculturated catechesis}

Inculturation of thinking is an essential aspect in catechesis. According to Mercado (1992), unless the Good News is made understood and meaningful, catechesis becomes merely the learning of concepts. For instance, fellow Christians may mouth love of enemies. But will most of them not take revenge when it comes to family honor? How do catechists explain the meaning of salvation in Philippine context and in Filipino categories? "The synthesis between culture and faith is not just a demand of culture, but also of faith. A faith which does not become culture is a faith which has not been fully received, not thoroughly thought through, not fully lived out" (John Paul II, 2002).

Inculturated Catechesis is holistic and hierarchical. It leads towards inculturated liturgy and sacraments. It is also oriented in justice and leads toward spirituality. What makes the Gospel and Tradition holistic vis-à-vis the Social Teachings of the Church is its presentation avoiding the "dichotomy of spiritual-earthly that would only 
concentrate on dogmas, sacraments and abstract moral principles." A holistic catechesis is one which leads into an experience of realizing one's vocation in life. Its goals are formative. "The hierarchical presentation of catechesis implies that it be explicitly Trinitarian and Christocentric. The whole catechesis must lead toward Christ, and to an intimate personal contact with Christ in the community of the believers" (Nemet, 2000).

Catechesis in its vertical process is rooted in the cultural, socio-political and economic context to help people stay in constant contact with God. This is itself is an act of inculturation in catechesis. Considering the relationship between the inculturated catechesis and the present context in the Philippines, it becomes evident that such a catechesis should prepare the catechized for an active involvement in the realization of the social thrust of the Gospel. On the other hand, according to Burke (2012), the horizontalization of the Catechetical process is deemed to respond to the needs of the Filipinos. How the sacraments are celebrated should be rooted in the Filipino culture with emphasis to the experiences of the people. For him, prayer and liturgy are never an escape from reality and history, or from involvement in "earthly" affairs. The unique characteristic of inculturated catechesis is that it leads towards an "inculturated liturgy".

\subsection{Communitarian catechesis}

The Catechetical Ministry should be the concern of every Christian. Hence, "Catechesis" which is a task of Evangelization should be fully supported by every Christian, materially as well as spiritually. This means all ecclesial structures of decision should be involved (Baccay, 2000). Religious instruction should be characterized by community-orientedness as prescribed by the Church. In the Catechetical Ministry, the frontliners are the Catechists who do the actual work of bringing the "Message of God" to the classrooms. Hence, the community of believers in a parish should give their all-out support, through their prayers, sacrifices and love offerings, so that every catechist will be able to perform his/her work effectively (Baccay, 2000).

All Filipino Catholics should be involved in the catechetical ministry. They should be made conscious and active through the light of instruction (Vat II, CD14), moving from merely being catechized to catechizing members - usually by working especially through family catechesis (cf. CBCP-ECCCE on the Catechetical Ministry). This is the challenging vocation of Christian parents to catechize their own children. "Parents are the primary educators in the faith. Together with them, all members of the family play an active part in the education of the younger members" (GDC, 255). Indeed, "family catechesis precedes... accompanies and enriches all catechesis" (GDC 226; CT 68).

In a family-centered culture such as the Philippines, the following directives of the late, and now St. John Paul II are especially pertinent: “The family's catechetical activity has a special character which is in a sense irreplaceable... Education in the faith by parents... should begin from the children's tenderest age... is more incisive when in the course of family events (reception of the sacraments, great liturgical feasts, the birth of a child, a bereavement), care is taken to explain in the home the Christian or religious content of these events" (CT 68). Filipino parents must be encouraged and helped in practical ways to carry out this mandate, especially through BEC activities and agencies engaged in family catechesis (cf. Rev. NCDP, 464).

\subsection{Renewed catechism for a renewed evangelization}

While "Catechesis" is God's Work; God, however, uses people as His instruments in making things happen. In order that God could use them to carry out His plans, these instruments should make themselves totally available to whatever may be the leading of the Holy Spirit for a truly effective "Catechesis." Hence, there is a need for fully dedicated people who would consider the Catechetical Ministry their primary concern and thus make themselves available to be used by God for this Great Mission of Evangelization (Baccay, 2000).

Responding to the challenge of the new millennium through a renewed catechism for a renewed evangelization, Mangibunong (1997) enumerated the following recommendations: 1) an on-going in-service program to be more updated with the current trends in Religious Education with emphasis on the awareness and 
observance of renewed catechesis such as: Christ-centered, Biblically-rooted, inculturated, integrated, and community-oriented as prescribed by the Church that should characterize religious instruction; 2) an acquisition of indispensable reading materials on catechesis; 3) giving more emphasis on the characteristics of renewed catechesis, namely: Christ-centeredness, Biblically rootedness, inculturatedness, integratedness and community-orientedness such that these become the basis for assessment of religious instruction in the schools; 4) maximizing the use of the Scripture in enriching the teaching of religion; and 5) witnessing the value of the Bible to inspire the students to live a meaningful life that is centered on Christ.

It should be noted that "the parish is without doubt, the most important locus in which the Christian community is formed and expressed. It constitutes a community space for the realization of the ministry of the Word at once as teaching, education and life experience" (GDC 257). The most practical goal for all parishes then is a renewed understanding and appreciation of the importance and centrality of the catechetical ministry itself, both for the life of the parish as a community, as well as for the faith-life of each member.

\subsection{Catechism envisioning the CICM mission and identity in education}

The religious education offered in CICM schools reflects real-life learning and not mere parroting of religious truths and doctrinal instructions. Hence, classroom encounters in catechism should actually lead the pupils to an understanding and experience of the Catholic faith through shepherding. Accompaniment is key to a personal experience of faith and community building. Religious educators and or catechists do not simply convey religious information in class. They are God's storytellers (Cura, 2016).

Student-catechists (as religious education facilitators themselves) must not simply introduce innovations to bring variety and sustain interest of pupils. They should adopt teaching-learning approaches in response to the Church's call to New Evangelization and Missionary Transformation. Their mission is to guide the pupils to be committed disciples of Jesus according to the charism and values of the Congregation of the Immaculate Heart of Mary, and University of Saint Louis as the academic institution where they belong. This is a very challenging enterprise that demands critical reflection and creativity: to figure ways to propose the Gospel that is "new in methods, new in ardour, new in expressions" (John Paul II, XIX Assembly, CELAM) to students in the 21st century.

Understanding the nature of the CICM approach towards religious education in the new millennium implies new designs for assessments. However, the key issue of assessment is not in the design. The catechists should be able to gauge if pupils display clear evidence of understanding and application of faith values learned in class. Was there ever a Jesus-encounter in class? Did everyone's heart 'burn' while pupils and missionary shepherds journey in class? These assessments will have to be designed to measure the achievement (or non-achievement) of concrete goals established at the outset. Performance and outcomes-based assessments are highly recommended because these instruments can evidence clearly student understanding and application. They can also help provide opportunities to connect concretely classroom learning, liturgical experiences and extension services (Cura, 2016). As regards the guide for teaching catechesis, Reblora (2016) found out that parish-based catechists properly use the syllabus, module, or lesson plan in teaching catechism to those who will receive the sacraments. One will easily see the conscious efforts of the catechists to use properly the syllabus, modules or lesson plans given to them.

\section{Conceptual framework}

The conceptual framework of the study was drawn from Catholic Church's documents on Religious Education at both national and international levels and from the work of researchers within the field of religious education and catechesis. As catechesis is distinct in its context in the Philippines, these essential documents became process reference in framing religious education in the catechetical program delivered by USL in particular. Specifically, the study investigated the efficiency of Religious Education in the Catechetical Program

66 Consortia Academia Publishing (A partner of Network of Professional Researchers and Educators) 
of the University with consideration of its quality of content and methodology. It is argued that these factors have significance in the development of an understanding of the role of the Religious Education in the formation of faith lives.

Moreover, this study is grounded on the catechetical theory or religious education which places emphasis on the development of the faith lives of the students and teachers. It is based upon the view that the school is a community of faith and that the activities that take place there are akin to what happens in the life of local parishes and families. Passing on of the tradition that encourages students to become more committed to the person of Jesus and to the church, is central to this theory. Furthermore, this theory is predicated upon the assumption that those who participate, both students and teachers, are willingly engaging in a dialogue among believers for the purpose of deepening faith.

Hence, guided by this theory, it is assumed that USL catechists transform their knowledge of the Christian faith into wisdom that builds and which cascades to the students in the catechetical schools. Whereas, if this religious or extension program of the University be in the right perspective - producing outcomes of students who are appreciative and become more faithful to the teachings of the church and imbibing in them the values expected of them - it should have been able to impinge a trademark that is unique to the Louisian culture of excellence and missionary identity. Thus, making the religious education in the catechetical program of the University successful in its goals.

\subsection{Research paradigm}

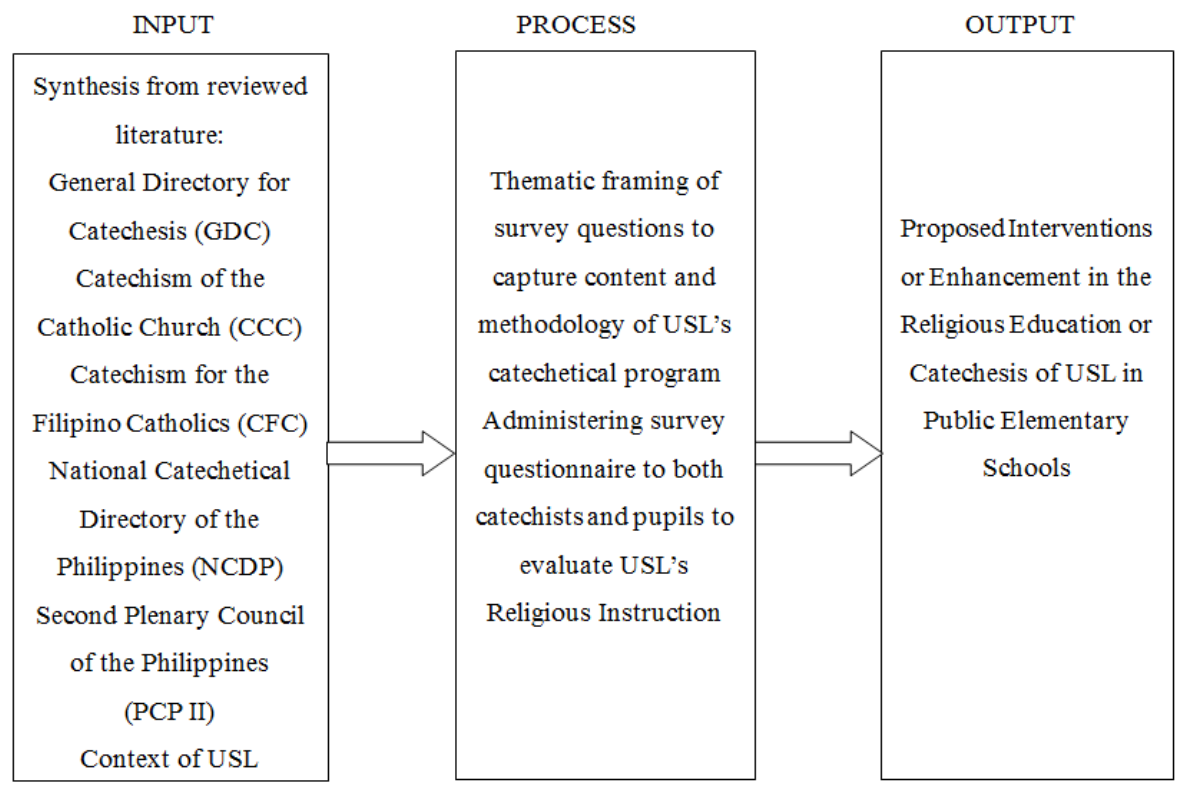

Figure 1. A paradigm showing the Input-Process-Output of the study.

\section{Methodology}

\subsection{Research design}

This study employed the mixed methods of research. The qualitative data covered the thematic analysis of USL's response and program alignment. The quantitative data were taken using a descriptive survey method with complete enumeration and ranking to evaluate the existing trends in the Religious Education/Instruction in the Catechetical Program of USL such as students' perceptions of their catechists' religious instruction and the values imbibed in them. 


\subsection{Respondents}

The respondents of this research were the 171 student-catechists of USL for the SY 2016-2017 and SY 2017-2018, and the 269 Grade 6 pupils who received catechesis from them. These student-catechists are the Third Year College students enrolled in Theology 6 for the first semester, and Theology 7 in the second semester under the Teacher Education Program of the SEASH Department for the previous school year (2016-2017), and currently for the school year (2017-2018). Complete enumeration was used in this study.

\subsection{Research instrument}

Essential Church documents and other readings became instruments in the synthesis that was drawn to frame the context of the religious education in the catechetical program of USL. The synthesis from the literatures reviewed along Church documents and other essential readings framed the content and methodology specific to the context of delivery of Religious Education in the Catechetical Program of USL. From the synthesis, what were commonly expressed in the literatures reviewed are the stories in God's self-revelation in the Old Testament, Christ's teachings in the Gospels being the Son of God, celebration of the sacraments in the Church, orthodoxy and orthopraxis in catechesis, and spiritual and moral development of persons. Emphatically, some authors dealt unity-in-diversity in theology and catechesis (Panganiban, 2010), catechetical themes focusing on doctrines, morals, prayer and worship (Fall, 2000; Roche, 1995; Tolhurst, 1993), content like God's Creation, Jesus' mission, Church, and sacraments (Ameche, 2005), the Ten Commandments and Basic Prayers (Lovasik \& Tolhurst, 1994), and development of frameworks and methodology (Santos, 2013; Schroeder, 2013; Baring, 2010; ICAM, 2016).

Essentially, relevant documents of the Catholic Church in the Philippines (Catechism for the Filipino Catholics, National Catechetical Directory of the Philippines, and the Second Plenary Council of the Philippines (PCP II - Maturing on Christian Faith) technically support the catechetical ministry through the provision of content and encouragement of enhanced methodology or pedagogy. According to the Catholic Bishops' Conference of the Philippines (CBCP), catechetical methodology is varied but every adequate catechetical methodology must be grounded explicitly on three (3) bases: Scripture, Tradition, and human experience. It is important to note how catechists are being prepared and guided in a solid foundation based on the aforementioned Church documents and other essential readings.

The study also made use of validated researcher-made survey questionnaire for student-catechists and elementary pupils. The survey questionnaire for student-catechists has two parts. Part 1 elicited their responses on the efficiency rating of the religious education in USL's catechetical program while Part 2 required them to respond to pedagogical items such as the materials they utilized in doing catechesis, the values they integrated in their lessons, the activities they used in teaching, and the comments they have with regard content and quality of USL's catechetical program.

The survey form questionnaire for the pupils has two parts. Part 1 asked for the pupils' rating of the extent of their learning in the light of the outcomes expected in USL's catechetical program whereas Part 2 elicited their rating of the extent to which the values are imbibed in them through USL's catechetical program. They were also asked to give more values they learned from the student-catechists and what comments could they give to improve the delivery of USL's catechetical instruction.

\section{Results and discussion}

\subsection{Extent of pupils' learning on catechetical instruction}

Despite being in a pluralistic classroom (where the pupils vary in their faith denominations), they were able to realize the complexity of multi-pluralism or multi-culturalism in the social context hence it came out from 
them that they do not forget to include in their prayers all other peoples in the world. Majority of the respondents have understood the culture of faith and or the faith of one's culture. The non-Catholic yet Christian pupils have affirmed positively the presence of the Louisian student-catechists. Many Catholic pupils who admitted being passive in their faith admitted of being motivated to become active by the "religious teaching" they experienced. It can be gleaned from the findings that the pupils yearn for the "promotion of dialogue of faith and life and culture". The comments "I am glad for having catechists from the University of Saint Louis who are good as missionaries" and "I am fully strengthening my faith in God based on the lessons I learn from my experiences" distinguished a "culture of mission and excellence" among the Louisian catechists. In one way or the other, USL, through its Religious Education in catechesis manifests the defining characteristics of an excellent Catholic school (see Philippine Catholic Schools Standards for Basic Education).

Santos (2013) said that there is no single best method of catechizing. The effectiveness of any methodology depends on its intelligent use. Thus, for USL to adopt its own methodology, as long as it is faithful to the content mandated by the Church, would not lead to any question in catechetical instruction. The kind of orthodoxy that should be proclaimed in catechesis is that which maintains the "received interpretation" of the Scriptures and does not question "historical continuity" interpreted through the signs of the times. It cannot be denied that culture and language evolve. Thus, the proclamation of one's faith in the catechism of the Church is not simply an intellectual way of interpreting the Scriptures. Rather, it is an expression of finding and giving meaning to many Christian practices which the catechumen should learn.

\subsection{Values imbibed by pupils}

USL's approach to catechesis is not only focused on the doctrinal level but also on the behavioral aspect of teaching-learning in its delivery of religious education. The zeal for catechesis in a doctrinal approach may no longer be transformative as it gives emphasis only on "knowing the doctrines of the Catholic Church by learning the contents of a Catholic catechism" or by "memorizing set answers to set questions contained within a catechism (Buchanan, 2005). It is good to note that there are many other approaches to catechism which the student-catechists in USL should learn. Based on Buchanan's "Pedagogical Drift: The Evolution of New Approaches and Paradigms in Religious Education, these approaches include: Kerygmatic, Life-centered, Shared Christian Praxis, Phenomenological, Typological, and Educational. On a final note, it is quite interesting that nine (9) of the pupils mentioned about respecting the religion of others while seven (7) admitted of learning the value of caring for the environment. These are values which the CICM adheres in the context of justice, peace, and integrity of creation. Indeed, the Louisian catechists carry with them the CICM charism in doing catechesis. Opportunities for pupils to have a meaningful catechism class with good catechists served as one outcome for the vision-mission of USL as Christian builder in the service of the Church and society. The Christian formation of Louisian catechists, in mission and excellence, made it to the point of giving inspiration even to non-Catholic Christians to appreciate the Catholic faith.

\subsection{Pupils' perception and recommendations on student-catechists' religious instruction}

Majority of the pupils observed many remarkable things about the student-catechists. Some pupils, however, noted several points for their improvement both in content and the manner of approach. Emphatically, imposing discipline in a strict sense while doing catechesis may unnecessarily lead the pupils to a loathsome connotation of being exploited to the dominant religion in the Philippines, the Catholic Faith. The catechists should be the voice of Christ who truly cares with respect to how pupils should be dealt with in the classroom. Though, it is a point for reflection to consider the appropriate content and methodology in catechism in a scholarly manner to properly guide the student-catechists and pupils in a holistic experience of teaching and learning. As what CBCP (1977) says: "The essence of the catechumenate should be an intense pedagogy towards Evangelical conversion" (see CBCP Position Paper on the Synod Theme "Catechetics in Our Time").

The completion of 15 units courses in Religious Education prior to exposure in catechesis with an additional 
6 units courses in the process of their catechetical exposure guides the Teacher Education students of USL to approaches in catechism which "can be viewed within a framework of distinguishable yet interrelated paradigms" (Buchanan, 2005). Indeed, for the student-catechists of USL to be sound in their catechetical ministry, their preparation should be developmental. This is why they also attend series of seminars and even recollection exclusive for catechists. How the content of the religious instruction be delivered in a manner that adheres with the Magisterium of the Church was given an utmost consideration. Hence, the disposition of the student-catechists (with their Catechetical Coordinator), and the pupils (with their classroom teachers) are viewed hereof as a factor also in the success of catechesis in public schools.

\subsection{Student-catechists' assessment of religious education in the catechetical program of USL}

Results show that students consider the Catechetical Program of USL as efficient. It serves as a point for reflection not only for these student-catechists themselves but also to whoever they interact with when it comes to the Catechetical Program that USL provides. What these Third Year college students in the SEASH Department learn from their teachers with the 18 units in Religious Education vis-à-vis their series of seminars with their Catechetical Coordinator should be well processed in their formation as catechists. They must understand that the "pedagogical techniques associated within each paradigm" (in the Religious Education courses that they take), and "their relationship with other approaches to religious education that best suit their own situation" could help them to be more "consistent with the role of religious education in a Catholic school" (Buchanan, 2005).

Students in USL who are enrolled in Religious Education courses have to learn both Catholic orthodoxy and Christian orthopraxis. For those being formed as catechists, in particular, having the CICM charism for school apostolate, they have to learn about Church doctrines, apostolic exhortations, and the encyclicals from the Magisterium. However, based on the data, very few of them thought of the Social Teachings of the Church, Gaudium et Spes, PCP II, CFC, NCDP, and CCC Teachings when asked to enumerate them. Not even a single Encyclical was mentioned. However, with regard to the content of the Christian message or the Theology in catechism, they are not far from knowing that the source of catechesis is the Word of God as they would always refer to the Bible when they talk about sacraments and parables. They just have to be guided that there are doctrines, encyclicals, or teachings of the Church which they should not overlook as credible sources in explaining better what the Scripture says.

The Louisian catechists, understandably are clever enough to use varied teaching-learning activities with their pupils in catechism. They are also good in providing assessments to what the pupils learn from them. How they teach the content is geared towards maturity in the Christian faith. Indeed, in catechism, it is not only the content that matters most but also the pedagogy. Catechists should keep themselves abreast with sound methodologies in the teaching-learning process. Indeed, the formation of student-catechists in USL is geared towards harnessing their "skills and imagination as agents of evangelization" (Baring, 2010).

According to Santos (2013), catechesis and catholic education need to re - focus on the following: content, learner, teacher, and process. Some student-catechists may have expressed negative feedback on their catechesis, albeit the positive outcome from the pupils who evaluated the Religious Education in the Catechetical Program of USL should be well considered. The rationale of such undesirable comments may be attributed also to the personal dispositions of the concerned student-catechists themselves because majority of them still reasonably believes in the quality of the Religious Education or catechesis they delivered. Nevertheless, the Catechetical Coordinator in charge of these catechists should untiringly guide and inspire them with developmental content and process in doing catechesis.

In this paper, there is no perceived gap between the student-catechists of USL and the pupils they serve with catechism using the CICM approach or methodology. Reasonably, both the Louisian catechists and their pupils in catechesis have inclinations to complement each other in the classroom. The encounter between the catechists

70 Consortia Academia Publishing (A partner of Network of Professional Researchers and Educators) 
Evaluation of the religious education in the catechetical program of the University of Saint Louis

and their pupils is a kind of linkage in which both are into religious education or catechesis being guided by the teaching authority of the Church.

\subsection{Recommendations for the religious education in the catechetical program of USL}

Based on the written comments of the pupils on the improvement of class in catechism and comments of the student-catechists on the content and quality of the religious education in the catechetical program of USL, there is a need to improve better in terms of pedagogy. The Religious Education (religious instruction) or catechesis being delivered should be utmost formative instead of being more informative. For even if the content of catechism is rich as spelled out in a syllabus, teaching module or lesson plan, if it does not make the pupils nor the student-catechists themselves to be essentially more spiritual or religious, such endeavor in catechesis would not be truly effective nor generally productive.

What the student-catechists learn or experience in USL in relation to their Theology and or Religious Education courses is not just simply for themselves because they are required to do catechesis. They have to proclaim the Good News which they heard in USL. They have to become agents of evangelization with the trademarks of excellence and professional responsibility. Thus, it would be good to consider how they are also guided by their Theology or Religious Education instructors as well as their appointed Catechetical Coordinator. The missionary zeal of USL with the tagline "Once a Louisian, always a missionary" should be expressed in virtues worth emulating from role modeling. Somehow, experiential learning follows the dictum "You cannot give what you do not have".

\section{Conclusion}

In the light of the foregoing findings, it is concluded that the religious education in the catechetical program of USL delivered in the public elementary schools adheres to the content and methodology as expected in the program. However, there is a need to reconcile these content and methodology in the light of principles of learning and methods of teaching applied in Religious Education. Whatever is new in the field of Education does not exempt the CICM schools, like University of Saint Louis Tuguegarao, in determining nuances that need to be addressed through liberal yet holistic teaching-learning styles. Though there is a perceived gap between the Catechetical Coordinator and the student-catechists to a certain extent, it must be noted that the student-catechists manage to deliver a CICM inspired way of educational apostolate through a relevant Catechism in the client schools for catechesis. The Louisian catechists' commitment in doing catechesis calls for constant information and guidance with their content and methodology which necessitates an open line of communication with regular giving of feedback on availability of resources and results of accomplishment in the delivery of catechism towards maturity of faith by everyone involved. This has important implications to the Religious Education and or catechesis which should keep itself abreast with contemporary methods in religious formation and instruction to respond to the sweeping conditions and transitions that mark education at present times. The bulk of catechism in traditional mode (like Baltimore catechism) is no longer the dominant approach in catechesis. Value-laden theological reflections that strengthen the faith are given utmost consideration to address the gaps of the Biblical narratives with the life stories of the younger generation today.

\section{References}

Ameche, G. SJ. (2005). Pampamayanang katesismo: Patnubay sa katekista. Philippines: Claretian Publications. Baccay, R. (2000). Status of the catechetical ministry of the archdiocese of Tuguegarao. Unpublished Masteral thesis, Lyceum of Aparri, Aparri, Cagayan.

Baring, R. (2010). A new approach to catechesis: Involving students in catechetical education in the Philippines. International Studies in Catholic Education, 2(2), 176-192. https://doi.org/10.1080/19422539.2010.504027

Benedict XVI. (2005). Compendium of the catechism of the Catholic Church. Manila: World and Life 
Temporal, W.

Publications.

Buchanan, M. T. (2005). Pedagogical drift: The evolution of new approaches and paradigms in religious education. Religious Education, 100(1), 20-37. https://doi.org/10.1080/00344080590904662

Burke, R. L. (2000). Commentary on the general directory for catechesis. The catholic faith. Retrieved from https://mariancatechist.com/commentary-on-the-general-directory-for-catechesis/

CBCP Online. (1977). CBCP position paper on the synod theme "Catechetics in our time". Retrieved June 19, 2018, from http://cbcponline.net/cbcp-position-paper-on-the-synod-theme-catechetics-in-our-time/

CBCP. (1991). Acts and decrees of the second plenary council of the Philippines. Manila: Catholic Bishop's Conference of the Philippines.

CBCP's Episcopal Commission on Catechesis and Catholic Education. (2020). The catechetical ministry. Retrieved October 30, 2020, from https://www.cbcp-eccce.org/catechetical/

Cura, E. (2016). Encountering Jesus on campus: Journey with students through Christian formation. CICM: Christian Formation Manual.

E.C.C.C.E. (1984). Maturing in Christian faith: National catechetical directory for the Philippines. Manila: Saint Paul Publications.

E.C.C.C.E. (1994). Catechism of the Catholic Church. Manila: Word and Life Publications.

E.C.C.C.E. (2005). Catechism for Filipino Catholics. Special subsidized edition for Filipino Catechists. Manila: CBCP.

Fall, R. (2000). Religious education curriculum guidelines for elementary catechesis. Department of Lifelong Faith Formation, Diocese of Buffalo. Retrieved July 19, 2016, from http://www.officeoflifelongfaithformation.org/Portals/8/PDF/Elementary\%20curriculum\%202000.pdf

Fleming, G. (2002). An assessment of religious education coordinators' perceptions of their roles in catholic secondary schools in the archdiocese of Melbourne. Retrieved August 31, 2017 from http://www.dcgary.org/pdf/goals-teaching-religion.pdf

Huebsch, B. (2004). The general directory for catechesis: in plain English. USA: A Division of Bayard.

ICAM (2016). Institute of catechetics of the archdiocese of Manila. Retrieved September 21, 2016, from http://www.cfamphil.org/icam

John Paul II. (1979). Apostolic exhortation catechesi tradendae, on catechesis in our time. Retrieved June 19, 2018 from, http://www.vatican.va/content/john-paul-ii/en/apost_exhortations/documents/hf_jp-ii_exh_16101979_c atechesi-tradendae.html

John Paul II. (2002). Message of John Paul II to Cardinal Paul Poupard for the 20th anniversary of the pontifical council for culture. Retrieved July 18, 2017, from http://www.vatican.va/content/john-paul-ii/en/messages/pont_messages/2002/documents/hf_jp-ii_mes_ 20020514_message-poupard.html

Lovasik, L. (1994). The apostolate's family catechism. Philippines: Apostolate for Family Consecration. Abridged Philippine Edition.

Mangibunong, R. (1997). Renewed catechesis in the light of PCP II: the case of CICM tertiary schools. Unpublished Masteral thesis, Saint Louis University, Baguio City.

Mercado, L. (1992). Inculturation and Filipino theology. Manila: Divine Word Publications.

Nemet, L., S.V.D. (2000). Inculturation of catechesis and spirituality in the documents of the catholic bishops' conference of the Philippines. Retrieved July 08, 2017, from http://eapi.admu.edu.ph/eapr95/nemet.htm

Panganiban, P. (2010). The development of the national catechetical directory for the Philippines (1985) and the Catechism for Filipino Catholics (1997):Model of inculturation. Unpublished Dissertation, The Catholic University of America, Washington, D. C. Retrieved September 19, 2016, from http://aladinrc.wrlc.org/bitstream/handle/1961/9220/Panganiban_cua_0043A0048display.pdf?sequence $=1$

Reblora, D. Q., Jr. (2016). An assessment on the extent of implementation of the diocesan catechetical program in district I and district III of the Diocese of Imus. The Online Journal of New Horizons in Education, 6(4). Retrieved from https://www.tojned.net/journals/tojned/articles/v06i04/v06i04-01.pdf

72 Consortia Academia Publishing (A partner of Network of Professional Researchers and Educators) 
Evaluation of the religious education in the catechetical program of the University of Saint Louis

Roche, J. (1995). Studying the new catechisms: Catechism of the Catholic church and catechism for Filipino catholics. Landas, 9, 101-125.

Roche, J. (2000). Revising the national catechetical directory. Landas, 14, 179-190.

Santos, G. (2013). The second Vatican council: Shifts, realizations and directions for catechesis and Catholic education in the Philippines. A paper delivered to UST Theology Week. Retrieved June 18, 2016, from http://www.pasigcatholic.edu.ph/wp-content/uploads/2015/01/the-second-vatican-council-shifts-realizat ions.pdf

Schroeder, C. (2013). The U.S. conference of Catholic bishops' doctrinal elements of a curriculum framework for the development of catechetical materials for young people of high school age: Pedagogical and theological perspectives of religious studies teachers in U.S. Catholic secondary schools. Unpublished Doctoral dissertation, University of San Francisco, San Francisco, California, USA. Retrieved June 18, 2016 from http://repository.usfca.edu/cgi/viewcontent.cgi?article $=1060$

Tolhurst, J. (1993). A concise catechism for Catholics: a simple exposition of catholic doctrine. Quezon City: Claretian Publications. 
Temporal, W.

74 Consortia Academia Publishing (A partner of Network of Professional Researchers and Educators) 